\title{
Efektivitas Biaya Strategi DOTS Program Tuberkulosis antara Puskesmas dan Rumah Sakit Swasta Kota Depok
}

\section{Cost Effectiveness of DOTS Strategy Tuberculosis Program Between Public Health Centre and Private Hospital At Depok City}

\author{
Fikrotul Ulya ${ }^{1}$, Hasbullah Thabrany ${ }^{2}$ \\ ${ }_{1}^{1}$ Pascasarjana IImu Kesehatan Masyarakat, Fakultas Kesehatan Masyarakat, Universitas Indonesia, Depok, Indonesia \\ ${ }^{2}$ Departemen Administrasi dan Kebijakan Kesehatan, Fakultas Kesehatan Masyarakat, Universitas Indonesia, Depok, Indonesia
}

Korespondensi: Fikrotul Ulya

e-mail:ulyafikrotul78@gmail.com

\begin{abstract}
Abstrak
Angka penemuan Tuberkulosis (TB) tahun 2016 adalah sebesar 77\% di dunia, sebesar 46,5\% di Asia Tenggara dan sekitar 32 - 33\% di Indonesia. Di Kota Depok angka penemuan TB mencapai 58\%. Sektor swasta menjangkau 18,7\% kasus TB di Kota Depok meskipun baru 40\% RS swasta yang terlibat. Penelitian ini bertujuan untuk mengetahui apakah penerapan strategi DOTS di Rumah Sakit swasta Kota Depok lebih menghemat biaya dibandingkan di Puskesmas. Penelitian dilakukan selama 6 bulan dengan kohort retrospektif di Puskesmas DOTS, RS DOTS dan RS Non DOTS menggunakan 36 sampel per kelompok. Penghitungan dari perspektif societal dengan microcosting berdasarkan tarif, harga pasar, serta nilai anggaran. Outputnya angka pengobatan lengkap (Success Rate). Hasil penelitian menunjukkan Success Rate di puskesmas paling tinggi yaitu 86,1\%, RS DOTS sebesar 77.78 \% dan Non DOTS 63.89\%. Penambahan biaya provider terutama tenaga pelaksana khusus di puskesmas dan RS DOTS meningkatkan success rate. Biaya societal di puskesmas $42 \%$ dari biaya di RS swasta. ACER (Average Cost Effectiveness Ratio) menunjukkan RS yang melaksanakan strategi DOTS lebih cost effective. Untuk menaikkan 1\% angka kesuksesan pengobatan membutuhkan biaya Rp 10.084.572 dengan melakukan intervensi program DOTS ke RS Swasta. Uji t independen menyatakan bahwa terdapat perbedaan bermakna biaya societal pengobatan tuberkulosis antara puskesmas, RS DOTS, dan RS Non DOTS.

Keywords : ACER, Cost Effectiveness Analysis, DOTS, ICER, RS Swasta, Success Rate
\end{abstract}

\begin{abstract}
Global TB notification rate at 2016 was $77 \%$ and $46.5 \%$ in Southeast Asia. Indonesia last 5 years still remain at 32-33\% where Depok City reached 58\%. In Depok City, private sector contributed 18.7\% of the notified TB case in 2016 although only 40\% of private hospitals were involved. The aims of this study is to determine cost-effectiveness of DOTS strategy implementation at private hospital and Public Health Centre (PHC). Comparative study carried out for six months with cohort retrospective between PHC, DOTS and Non DOTS hospitals using 36 samples per group. The calculation of the societal perspective with microcosting based on tariffs, market prices and budget value. Output is Success Rate, where at PHC 86.1\%, DOTS hospital 77.78\% and Non DOTS hospital 63.89\%. The addition cost providers especially person in charge at PHC and DOTS hospital increase success rate. The cost of TB treatment in PHC 42\% of private hospital. ACER (Average Cost Effectiveness Ratio) is obtained that the hospital which carry out the DOTS strategy is cost effective. To increase 1\% success rate of TB treatment costs Rp 10,084,572 with intervention DOTS programs into a private hospital. An Independen t test stated that cost-effectiveness societal perspectives on TB treatment has a significant difference between PHC, DOTS hospital and Non DOTS hospital .

Keywords: ACER, Cost effectiveness analysis, DOTS, ICER, Private hospital, Success Rate.
\end{abstract}

\section{Pendahuluan}

Angka penemuan kasus atau dikenal Case Detection Rate (CDR) merupakan indikator pencapaian program Tuberkulosis (TB). Menurut Global Tuberculosis Report 2016, angka penemuan kasus TB di dunia yaitu sebesar 46,5\% dan di kawasan Asia Tenggara sebesar 46,5\%. Di Indonesia angka penemuan kasus TB dalam 5 tahun terakhir mengalami titik stagnan yaitu 32 - 33\% kasus (WHO, 2016). Di kota Depok yang angka penemuan kasus TB yaitu sebesar 50-58\% kasus. Selain itu, juga terjadi peningkatan kasus TB kambuh sebesar 600\% (23 menjadi 177 kasus) dari tahun 2014 sampai 2016. Dinas Kesehatan harus mewaspadai hal ini dikarenakan, 12\% kasus TB MDR berasal dari kasus TB kambuh.

Setiap pencegahan kasus TB dapat menghemat beban biaya yang dikeluarkan pemerintah. Biaya yang dikeluarkan untuk penemuan dan penanganan tuberkulosis mencapai \$100-1000 sedangkan bila jatuh ke dalam kondisi MDR biaya yang dikeluarkan menjadi \$ 2000 - 20.000 (Laurence, Griffiths and Vassall, 2015; WHO, 2016). Pencegahan kasus TB dapat menghemat biaya sistem kesehatan hingga 
$\$ 171$ dan menghemat pengeluaran keluarga hingga \$791. Untuk TB MDR, biaya yang dapat ditekan mencapai $\$ 4,972$ dan beban keluarga mencapai $\$ 4,077$. Kasus TB MDR juga dapat menurunkan produktivitas hingga 40\% (Laurence, Griffiths and Vassall, 2015).

Strategi global WHO dalam penemuan kasus TB yaitu dengan melibatkan layanan kesehatan non pemerintah yang dinamakan Public-Private Mix (PPM), hal ini dikarenakan sebanyak $36 \%$ kasus TB didiagnosis di luar puskesmas (WHO, 2016). PPM terbukti dapat meningkatkan angka penemuan kasus TB sampai dengan 20\% (Mantala et al., 2003; Ahmed et al., 2009; Dey, 2017). Penelitian Reviono et al. (2017) di Jawa Tengah dihasilkan bahwa sejak implementasi PPM tahun 2003 terdapat kenaikan CDR dari 13\% menjadi 61,72\% di tahun 2014.

Strategi penanggulangan TB di kota Depok sudah melibatkan fasilitas kesehatan (faskes) swasta seperti klinik dan rumah sakit. PPM telah diaktifkan pada tahun 2014 dengan mengadakan pelatihan DOTS pada semua petugas puskesmas yang terlibat (dokter, perawat, dan analis laboratorium) dan 56 tenaga faskes swasta yang terdiri dari 10 dan 18 klinik swasta. Meskipun hanya 4 RS yang aktif membuka DOTS tetapi berhasil menjaring 18,7\% pasien BTA positif pada seluruh Kota Depok. Dengan demikian, keterlibatan pihak swasta perlu digalakkan. Oleh karena itu, melalui penelitian ini diharapkan dapat memperoleh nilai efektivitas biaya pengobatan TB antara di puskesmas menggunakan DOTS, RS yang menggunakan DOTS, dan RS yang belum menggunakan DOTS di Kota Depok tahun 20172018 sehingga dapat menjadikan pertimbangan dalam strategi penanganan program TB untuk mendukung implementasi SPM bidang kesehatan di Kota Depok.

\section{Metode Penelitian}

Penelitian ini merupakan penelitian evaluasi ekonomi model cost effectiveness analysis dengan studi kohort retrospektif. Dalam penelitian ini, peneliti mengikuti pasien sejak terdiagnosis TB atau minimal masih dalam tahap intensif pengobatan TB sampai pasien dinyatakan sembuh oleh pemeriksa. Biaya yang dihitung adalah biaya dalam perspektif societal dimana dihitung biaya pasien dan biaya provider (penyedia layanan kesehatan). Output yang dipakai untuk mengukur penanganan $\mathrm{TB}$ adalah angka pengobatan lengkap (Success Rate).
Penelitian terbagi 3 kelompok, yaitu kelompok pasien diobati di Puskesmas dengan DOTS, kelompok di RS swasta DOTS, dan kelompok di RS swasta tanpa DOTS. Hasil perhitungan rumus uji hipotesis beda proporsi didapatkan jumlah minimal sampel 36 orang per kelompok (Lemeshow et al., 1990). Kriteria inklusi dari penelitian ini adalah pasien TB dewasa (lebih dari 14 tahun), klasifikasi diagnosis TB dengan pengobatan OAT Kategori 1 atau rencana pengobatan TB selama 6 bulan, dan tidak ada penyulit atau penyakit lain. Kriteria eksklusi adalah pasien TB dengan pengobatan OAT kategori 1 yang tidak bersedia menjadi responden dan pasien yang pada saat pengamatan didapatkan penyakit lain.

Penelitian dilakukan di tiga Puskesmas, satu poliklinik RS dengan DOTS, dan satu poliklinik RS Non DOTS di Kota Depok. Penelitian ini menggunakan data primer dari hasil wawancara yang dilakukan sebanyak tiga kali. Wawancara dilakukan pada saat pasien pertama kali terdiagnosis TB, pada saat pasien masuk bulan ke empat, dan pada saat pasien dinyatakan sembuh. Pemantauan pasien dilakukan dengan wawancara melalui telepon. Wawancara juga dilakukan untuk mengetahui biaya yang diperlukan untuk pelayanan program TB. Data sekunder didapat dari status pasien, data billing, Form TB 01 pasien, data SITT, dan data laporan program TB puskesmas dan klinik tahun 2017.

Biaya pasien adalah biaya yang dikeluarkan pasien dari sejak terdiagnosis TB atau minimal masih dalam tahap intensif pengobatan TB sampai pasien dinyatakan sembuh. Biaya langsung terbagi menjadi biaya yang dikeluarkan pasien untuk mendapatkan layanan kesehatan (meliputi biaya konsultasi, biaya pemeriksaan penunjang seperti pemeriksaan dahak atau pemeriksaan $\mathrm{X}$ foto thorax, dan biaya obat baik obat TB paru maupun obat penunjang) serta biaya Langsung non medis (meliputi biaya transport, biaya pengantar, dan biaya lain-lain).

Biaya tidak langsung, yaitu biaya penghasilan pasien yang hilang karena berkunjung ke faskes. Untuk pasien pelajar/mahasiswa tidak dilakukan penghitungan pendapatan, sedangkan untuk pasien yang tidak bekerja seperti ibu runah tangga didapatkan dari nilai median dari responden yang mendapatkan penghasilan.

Biaya penyedia layanan kesehatan (Provider cost) dihitung selama tahun 2017. Biaya Langsung meliputi Fixed dan Variable cost. Fixed Cost didapat dari 
menghitung biaya investasi, yaitu tenaga pelaksana khusus klinik DOTS, ruangan yang digunakan dengan memperhitungkan rasio pemakaian dengan penghitungan biaya pembangunan ruangan sebesar Rp 3.500.000 pada tahun 2015, dan alat TCM hasil hibah. Biaya capital ini dilakukan penyesuaian dengan AIC, dimana tingkat inflasi 2017 sebesar 4\%. Variable Cost, terdiri dari bahan habis pakai laboratorium hibah, berupa Cartridge TCM seharga Rp 160.000 (harga dari medquest.com), pot dahak, dan reagen Ziehl Nielsen sesuai SHB (Standar Harga Barang) Dinas Kesehatan Kota Depok.

Biaya Tak Langsung merupakan biaya Program, meliputi biaya start up program (bila ada), honor pemegang program, pelatihan, insentif, promosi kesehatan, koordinasi, serta monitoring dan evaluasi. Uji hipotesis analisis bivariat menggunakan SPSS dengan Independen $t$ test. Variabel dependen adalah hasil pengobatan yang berskala kategorik, sedangkan variabel independen adalah biaya yang berskala numerik. Kemudian melakukan analisis sensitivitas.

\section{Hasil Penelitian}

\section{Profil Tempat Penelitian}

Program DOTS yang mengikuti Pedoman penatalaksanaan TB Kemenkes mulai dijalankan sejak tahun 2000 di 35 puskesmas Kota Depok. Pada tahun 2015 diadakan Pelatihan DOTS untuk semua petugas puskesmas. Rumah sakit mulai menerapkan strategi DOTS sejak tahun 2006. Di tahun 2015, sebanyak 4 orang pelaksana khusus ditugaskan bekerja setiap hari di Poli DOTS. Puskesmas dan RS DOTS sudah menggunakan SITT (Sistem Informasi Tuberkulosis Terpadu).

Sementara untuk rumah sakit yang belum menerapkan strategi DOTS, rumah sakit memberikan tugas tambahan pada tenaga perawat di poli paru untuk melakukan pencatatan TB meskipun belum mendapatkan pelatihan tentang TB (Tabel 1).

\section{Karakteristik Responden}

Responden yang diikuti dengan metode kohort retrospektif sejak bulan Oktober 2017 sampai dengan April 2018 berjumlah 36 dari masing-masing lokasi penelitian. Karakteristik data yang dikumpulkan berdasarkan hasil wawancara dan penelusuran hasil pengobatan dari 108 responden (Tabel 2).

Dari aspek demografis, sebagian besar responden di Puskesmas sebagian besar responden berjenis kelamin laki-laki sementara di rumah sakit sebagian besar berjenis kelamin perempuan. Responden masih dalam usia produktif dan rata-rata umur responden di tiap lokasi 34 - 38 tahun.

Berdasarkan cara pembayaran, lebih dari 70\% responden merupakan peserta BPJS Kesehatan. Tingkat pendidikan sebagian besar SMA. Berdasarkan hasil pengobatan, untuk fasilitas kesehatan dengan DOTS memiliki angka kesuksesan yang baik yaitu di puskesmas sebesar 86,11\% dan di RS DOTS 77,78\% sedangkan untuk Tanpa DOTS hanya berkisar $63,89 \%$.

Tabel 1. Perbandingan Faskes Penelitian Strategi DOTS

\begin{tabular}{|c|c|c|c|}
\hline URAIAN & PKM & RS DOTS & RS NON DOTS \\
\hline Penerapan DOTS & Sejak 2000 & Sejak 2006 & Belum DOTS \\
\hline Status Kepemilikan & Faskes Pemerintah & Faskes Swasta & Faskes swasta \\
\hline Waktu Pelayanan & Poli DOTS 2 kali/minggu & Poli DOTS 3 x/minggu & $\begin{array}{c}\text { Poli DOTS = Poli Paru } 6 \\
\text { x / minggu }\end{array}$ \\
\hline SDM & $\begin{array}{c}\text { TIM : } 1 \text { Dokter, } 1 \text { Perawat, } \\
2 \text { Analis terlatih }\end{array}$ & $\begin{array}{c}\text { TIM : } 2 \text { Dokter Paru, } 4 \\
\text { Perawat, } 1 \text { Analis terlatih }\end{array}$ & $\begin{array}{c}\text { TIM : } 3 \text { Perawat rangkap } \\
\text { tugas poli }\end{array}$ \\
\hline Tipe Faskes TB & $\begin{array}{l}\text { PKM rujukan mikroskopis, } \\
\text { Memiliki TCM }\end{array}$ & $\begin{array}{l}\text { RS rujukan mikroskopis; } \\
\text { Memiliki TCM }\end{array}$ & RS rujukan mikroskopis; \\
\hline Kemampuan TCM & Tersedia & Tersedia & Tidak tersedia \\
\hline OAT & OAT KDT & OAT KDT & OAT lepasan \\
\hline Penggunaan SITT & $\operatorname{SITT}(+)$ & $\operatorname{SITT}(+)$ & $\operatorname{SITT}(-)$ \\
\hline Status Intervensi & Komparator & PPM DOTS & PPM Tanpa DOTS \\
\hline
\end{tabular}


Tabel 2. Karakteristik Responden

\begin{tabular}{|c|c|c|c|c|c|c|}
\hline \multirow{2}{*}{ Profil Pasien } & \multicolumn{2}{|c|}{ PUSKESMAS } & \multicolumn{2}{|c|}{ RS DOTS } & \multicolumn{2}{|c|}{ RS NON DOTS } \\
\hline & Jumlah & $\%$ & Jumlah & $\%$ & Jumlah & $\%$ \\
\hline \multicolumn{7}{|l|}{ Jenis Kelamin: } \\
\hline Laki-laki & 22 & 61,11 & 14 & 38.89 & 16 & 44.44 \\
\hline Perempuan & 14 & 38,89 & 22 & 61.11 & 20 & 55.56 \\
\hline \multicolumn{7}{|l|}{ Kelompok Umur: } \\
\hline$<21$ tahun & 2 & 5,56 & 1 & 2,78 & 6 & 16,67 \\
\hline $21-30$ tahun & 10 & 27,78 & 9 & 25,00 & 9 & 25,00 \\
\hline $31-40$ tahun & 9 & 25,00 & 14 & 38,89 & 9 & 25,00 \\
\hline $41-50$ tahun & 9 & 25,00 & 5 & 13,89 & 8 & 22,22 \\
\hline$>50$ tahun & 6 & 16,67 & 7 & 19,44 & 4 & 11,11 \\
\hline \multicolumn{7}{|c|}{ Berdasarkan Cara Pembayaran: } \\
\hline Tunai & 13 & 36,11 & 5 & 13,89 & 7 & 19,44 \\
\hline Asuransi & 0 & 0,00 & 3 & 8,33 & 2 & 5,56 \\
\hline BPJS Kesehatan & 23 & 63,89 & 28 & 77,78 & 27 & 75,00 \\
\hline \multicolumn{7}{|c|}{ Penyebab Kunjungan: } \\
\hline Sendiri/Keluarga & 31 & 86,11 & 25 & 69,44 & 12 & 33,33 \\
\hline Rujukan Faskes & 3 & 8,33 & 11 & 30,56 & 24 & 66,67 \\
\hline Rujuk Balik & 2 & 5,56 & 0 & 0,00 & 0 & 0,00 \\
\hline \multicolumn{7}{|l|}{ Tingkat Pendidikan: } \\
\hline $\mathrm{SD}$ & 6 & 16,67 & 5 & 13,89 & 3 & 8,33 \\
\hline SMP & 10 & 27,78 & 5 & 13,89 & 4 & 11,11 \\
\hline SMA & 17 & 47,22 & 15 & 41,67 & 22 & 61,11 \\
\hline $\mathrm{D} 3 / \mathrm{S} 1 / \mathrm{S} 2$ & 3 & 8,33 & 11 & 30,56 & 7 & 19,44 \\
\hline \multicolumn{7}{|l|}{ Hasil Pengobatan: } \\
\hline Sembuh & 31 & 86,11 & 28 & 77,78 & 23 & 63,89 \\
\hline Drop Out & 3 & 8,33 & 7 & 19,44 & 13 & 36,11 \\
\hline Gagal Konversi & 2 & 5,56 & 1 & 2,78 & 0 & 0,00 \\
\hline
\end{tabular}

Tabel 3. Variasi Jenis Pemeriksaan Penunjang Sebelum Penegakan Diagnosis

\begin{tabular}{lcccccc}
\hline \multirow{2}{*}{ Jenis Pemeriksaan } & \multicolumn{2}{c}{ PUSKESMAS } & \multicolumn{2}{c}{ RS DOTS } & \multicolumn{2}{c}{ RS NON DOTS } \\
\cline { 2 - 7 } & Jumlah & $\begin{array}{c}\text { Persentase } \\
(\%)\end{array}$ & Jumlah & $\begin{array}{c}\text { Persentase } \\
(\%)\end{array}$ & Jumlah & $\begin{array}{c}\text { Persentase } \\
(\%)\end{array}$ \\
\hline $\begin{array}{l}\text { Belum ada } \\
\text { pemeriksaan }\end{array}$ & 20 & 55,56 & 14 & 38,89 & 22 & 61,11 \\
\hline $\begin{array}{l}\text { Pemeriksaan BTA } \\
\text { Biopsi PA, dll }\end{array}$ & 1 & 2,78 & 3 & 8,33 & 1 & 2,78 \\
\hline $\begin{array}{l}\text { BTA dan X foto } \\
\text { Thorax }\end{array}$ & 9 & 16,67 & 6 & 16,67 & 8 & 22,22 \\
\hline
\end{tabular}


Tabel 4. Penghitungan Biaya Pengobatan TB per Fasyankes

\begin{tabular}{|c|c|c|c|}
\hline URAIAN BIAYA & PUSKESMAS & RS DOTS & RS NON DOTS \\
\hline \multicolumn{4}{|l|}{ BIAYA PASIEN : } \\
\hline \multicolumn{4}{|l|}{ Biaya Langsung Medis : } \\
\hline a. Biaya Konsultasi & $\begin{array}{c}22,6 \pm 3,9 \\
(16-30)\end{array}$ & $\begin{array}{c}1.375,7 \pm 209,1 \\
(1.080-1.980)\end{array}$ & $\begin{array}{c}1.161,7 \pm 120,3 \\
(960-1.440)\end{array}$ \\
\hline b. Biaya Pemeriksaan Dahak & $\begin{array}{c}34,2 \pm 6,7 \\
(10-40)\end{array}$ & $\begin{array}{c}210,7 \pm 152,4 \\
(0-400)\end{array}$ & $\begin{array}{c}279,8 \pm 77,6 \\
(165-330)\end{array}$ \\
\hline c. Biaya $\mathrm{X}$ foto Thorax & $\begin{array}{c}11,3 \pm 26,2 \\
(0-70)\end{array}$ & $\begin{array}{l}154,3 \pm 144,6 \\
(0-360)\end{array}$ & $\begin{array}{c}388,3 \pm 107,7 \\
(229-458)\end{array}$ \\
\hline d. Biaya OAT & $360 \pm 0$ & $360 \pm 0$ & $\begin{array}{c}581,3 \pm 526,8 \\
(435,2-2.957,3)\end{array}$ \\
\hline e. Biaya Laboratorium lainnya & $\begin{array}{c}16,5 \pm 39,9 \\
(0-210)\end{array}$ & $\begin{array}{c}75,6 \pm 86,2 \\
(20-283)\end{array}$ & $\begin{array}{c}147,8 \pm 87,3 \\
(0-340,5)\end{array}$ \\
\hline f. Biaya Obat selain OAT & $\begin{array}{l}6,8 \pm 2,0 \\
(0-11,3)\end{array}$ & $\begin{array}{c}88,9 \pm 79,2 \\
(0-240)\end{array}$ & $\begin{array}{c}111,5 \pm 169,4 \\
(0-818,1)\end{array}$ \\
\hline Subtotal Biaya Langsung Medis & $\begin{array}{c}451,4 \pm 47,3 \\
(389,4-633,3)\end{array}$ & $\begin{array}{c}2.265,2 \pm 366,1 \\
(1.460-3.130)\end{array}$ & $\begin{array}{c}2.670,5 \pm 708,3 \\
(1.949,2-5.574,9)\end{array}$ \\
\hline
\end{tabular}

Biaya Langsung Non Medis :

a. Biaya Transportasi :

\begin{tabular}{|c|c|c|c|}
\hline Biaya Pendaftaran & - & $\begin{array}{l}21,8 \pm 18,6 \\
\quad(0-70)\end{array}$ & $\begin{array}{l}31,7 \pm 22,2 \\
(0-96)\end{array}$ \\
\hline Biaya Pengambilan Obat & - & - & $\begin{array}{l}34,3 \pm 26,4 \\
(0-98)\end{array}$ \\
\hline Biaya Pelayanan Medis & $\begin{array}{l}59,6 \pm 36,6 \\
(0-190)\end{array}$ & $\begin{array}{c}109,7 \pm 103,5 \\
(29,2-440)\end{array}$ & $\begin{array}{l}76,7 \pm 58,3 \\
(34,4-296)\end{array}$ \\
\hline Subtotal Biaya Transportasi & $\begin{array}{l}59,6 \pm 36,6 \\
(0-190)\end{array}$ & $\begin{array}{c}131,5 \pm 97 \\
(51,4-440)\end{array}$ & $\begin{array}{c}142,8 \pm 87,3 \\
(41,3-408)\end{array}$ \\
\hline b. Biaya Makan,dll & $\begin{array}{l}47,3 \pm 76,5 \\
(0-323)\end{array}$ & $\begin{array}{l}24,3 \pm 45,3 \\
(0-195)\end{array}$ & $\begin{array}{l}71,4 \pm 74,6 \\
(0-210)\end{array}$ \\
\hline $\begin{array}{l}\text { Subtotal Biaya Langsung Non } \\
\text { Medis }\end{array}$ & $\begin{array}{c}98,5 \pm 64,5 \\
(60-295)\end{array}$ & $\begin{array}{c}155,8 \pm 115,9 \\
(57,7-551)\end{array}$ & $\begin{array}{c}214,3 \pm 105,4 \\
(84,1-568)\end{array}$ \\
\hline Biaya Tidak Langsung & $\begin{array}{c}689,0 \pm 482 \\
(88,8-2.000)\end{array}$ & $\begin{array}{l}525,5 \pm 280,3 \\
(0-1.350)\end{array}$ & $\begin{array}{l}549,5 \pm 367,5 \\
(0-1.750)\end{array}$ \\
\hline Total Biaya Pasien & $\begin{array}{c}1.238,9 \pm 524,6 \\
(484,3-2.928)\end{array}$ & $\begin{array}{c}2.946,6 \pm 537,1 \\
(1.518-5.031) \\
\end{array}$ & $\begin{array}{c}3.434,2 \pm 775,3 \\
(2.033-7.892) \\
\end{array}$ \\
\hline \multicolumn{4}{|l|}{ BIAYA PROVIDER : } \\
\hline Biaya langsung Fixed Cost & $65,6 \pm 0$ & $27,2 \pm 0$ & $1,9 \pm 0$ \\
\hline Biaya langsungVariabel Cost & $\begin{array}{l}343,5 \pm 58,8 \\
(242,7-455)\end{array}$ & $\begin{array}{l}122,9 \pm 18,7 \\
(96,5-177)\end{array}$ & 0 \\
\hline Biaya Langsung Provider & $\begin{array}{c}409,1 \pm 58,8 \\
(308,3-520,7)\end{array}$ & $\begin{array}{c}150,2 \pm 18,7 \\
(123,8-204,2)\end{array}$ & $1,9 \pm 0$ \\
\hline Biaya Tak langsung Provider & $29,7 \pm 0$ & $6,3 \pm 0$ & $7,8 \pm 0$ \\
\hline Total Biaya Provider & $\begin{array}{r}438,8 \pm 58,8 \\
(338-550,3)\end{array}$ & $\begin{array}{c}156,5 \pm 18,7 \\
(130,1-210,5)\end{array}$ & $9,7 \pm 0$ \\
\hline BIAYA SOCIETAL & $\begin{array}{c}1.677,7 \pm 529,8 \\
(822,2-3.478,5)\end{array}$ & $\begin{array}{c}3.103,1 \pm 550,4 \\
(1.648-5.241)\end{array}$ & $\begin{array}{c}3.443,9 \pm 775,3 \\
(2.033-7.893)\end{array}$ \\
\hline
\end{tabular}

Keterangan : Biaya dalam ribuan rupiah

\section{Penghitungan Biaya}

Sebelum penatalaksanaan TB di faskes, pasien mempunyai berbagai riwayat pencarian diagnosis yang berasal dari berbagai macam faskes. Hal ini nanti akan mempengaruhi mempengaruhi biaya langsung medis karena akan terjadi perbedaan biaya antara responden yang belum dilakukan pemeriksaan apapun dengan responden yang merupakan kasus rujukan.

Dari tabel 3 didapatkan bahwa di sebagian 
Tabel 5. Penghitungan ACER per Faskes

\begin{tabular}{lccc}
\hline URAIAN & PUSKESMAS & RS DOTS & RS NON DOTS \\
\hline Biaya Pasien (Rp) & 1.238 .910 & 2.946 .563 & 3.434 .208 \\
\hline Biaya Provider (Rp) & 438.757 & 156.529 & 9.670 \\
\hline Biaya Societal (Rp) & 1.677 .667 & 3.103 .092 & 3.443 .877 \\
\hline Success Rate (\%) & 86,10 & 77,78 & 63,89 \\
\hline ACER & $1.677 .667 / 86,10$ & $3.103 .092 / 77,78$ & $3.443 .877 / 63,89$ \\
& $=\mathbf{1 . 9 4 8 . 2 8 4}$ & $\mathbf{3 . 9 8 9 . 5 7 6}$ & $=\mathbf{5 . 3 9 0 . 3 2 3}$ \\
\hline
\end{tabular}

Tabel 6. Hubungan Biaya Pengobatan dengan Hasil Pengobatan TB

\begin{tabular}{lcc}
\hline \multicolumn{1}{c}{ Jenis Biaya } & $\begin{array}{c}\text { Levene's Test for Equality of } \\
\text { Variances }\end{array}$ & Sig. (2-tailed) \\
\hline Total Biaya Langsung Medis & 0,000 & 0,030 \\
\hline Total Biaya Langsung Non Medis & 0,135 & 0,005 \\
\hline Biaya Tak langsung Pasien & 0,006 & 0,674 \\
\hline Total Biaya Pasien & 0,173 & 0,016 \\
\hline Biaya Langsung Fixed Cost & 0,219 & 0,031 \\
\hline Biaya Langsung Variable Cost & 0,001 & 0,001 \\
\hline Biaya Tak langsung provider & 0,000 & 0,097 \\
\hline Total Biaya Provider & 0,001 & 0,002 \\
\hline Biaya Societal & 0,703 & 0,001 \\
\hline
\end{tabular}

besar pasien puskesmas dan RS Non DOTS belum dilakukan pemeriksaan untuk penegakan diagnosis TB sedangkan di RS rujukan DOTS hanya $39 \%$ yang belum dilakukan pemeriksaan.

Penghitungan biaya pengobatan TB per fasyankes dapat dilhat pada tabel 4. Setelah mendapatkan biaya societal, maka dapat dihitung nilai ACER (Average Cost Effectiveness Ratio). Dalam menentukan penghitungan nilai ACER didapatkan dari pembagian penjumlahan seluruh biaya intervensi dibagi dengan success rate yang didapatkan selama penelitian.

Setelah mendapatkan biaya societal, maka dapat dihitung nilai ACER (Average Cost Effectiveness Ratio). Dalam menentukan penghitungan nilai ACER didapatkan dari pembagian penjumlahan seluruh biaya intervensi dibagi dengan success rate yang didapatkan selama penelitian (Tabel 5).

Nilai biaya masyarakat/societal puskesmas paling rendah yaitu Rp. 1.677.667 per pasien TB pengobatan lengkap. Perbedaan nilai ACER untuk RS DOTS 201\% dan untuk RS Non DOTS 273\%. Apabila antar RS dibandingkan, nilai ACER RS DOTS lebih rendah 35\% dibandingkan RS Non DOTS. Jadi dapat dikatakan bahwa untuk RS yang sudah bekerjasama dengan pemerintah dengan menerapkan program DOTS membutuhkan biaya Rp 3.989 .576 per $1 \%$ kenaikan success rate. Sedangkan di Puskesmas sebagai penanggung jawab program di masyarakat hanya membutuhkan biaya Rp 1.948 .284 per $1 \%$ kenaikan success rate pasien TB.

Analisis statistik dilakukan untuk melihat apakah terdapat perbedaan efektivitas biaya pada pengobatan TB di puskesmas, RS dengan DOTS, dan RS Non DOTS di Kota Depok tahun 2017-2018, yang hasilnya terdapat pada Tabel 6. Hasil uji statistik didapatkan bahwa nilai Levene's test menunjukkan data mempunyai varian yang berbeda yaitu 0,703 (p value $>0,05$ ) maka data terdistribusi normal sedangkan hasil analisa $t$ test didapat $p$ value $<0,05$ baik perspektif pasien ( $p$ value $=0,016)$, perspektif provider $(p$ value $=0,002)$, maupun perspektif societal ( $p$ value $=0,001)$. Artinya terdapat perbedaan bermakna efektivitas biaya pada pengobatan TB di puskesmas, RS dengan DOTS, dan RS Non DOTS di Kota Depok tahun 2017-2018 baik dari perspektif pasien, provider, maupun masyarakat/societal. Hal ini sejalan dengan penelitian Mahendradhata, et.al (2010) dengan $p$ value sebesar 0,01 tetapi hanya menganalisis dari perspektif pasien.

Pada penelitian ini digunakan one way sensitivity analysis. Sebelum dilakukan analisis sensitivitas, dilihat nilai Levene's test untuk melihat distribusi data. Tes menunjukkan data mempunyai varian yang berbeda yaitu 0,703 ( $p>0,05)$ maka data terdistribusi 
normal sedangkan hasil analisa t test didapat $\mathrm{p}$ value $0,001(\mathrm{p}<0,05)$ artinya data yang didapat bermakna secara statistik.

Pada analisis sensitivitas yang digunakan sebagai base-case adalah biaya societal yang didapat dari masing-masing faskes dengan variasi $\pm 10 \%$. Data yang pasti /certain baik di puskesmas, RS DOTS, maupun RS Non DOTS pada umumnya adalah biaya langsung medis seperti biaya konsultasi, biaya OAT, dan biaya provider. Hal ini karena data yang didapat berdasarkan tarif dan data muncul di semua responden. Data yang tidak pasti (uncertain) pada umumnya biaya langsung non medis seperti biaya transportasi, dan makan. Biaya tak langsung berupa productivity loss, serta biaya tambahan diluar standar alur pelayanan karena data tidak muncul di semua responden dan variasinya terlalu lebar sehingga nilainya terdistribusi tidak merata.

\section{Pembahasan}

Ketika DOTS diterapkan secara komprehensif, ada kepercayaan dari pasien untuk mengikuti pengobatan di suatu faskes, mengingat pengobatan TB yang membutuhkan waktu 6 bulan untuk mencapai kesembuhan. Pasien juga merasa mendapatkan informasi yang cukup dan dukungan saat pengobatan (Suhariadi et al., 2016; Getahun and Nkosi, 2017). Kelebihan RS Swasta dibanding faskes milik pemerintah seperti puskesmas adalah respon lebih cepat, waktu bisa lebih fleksibel dan pelayanan lebih lengkap (Putri and Hisyam, 2014).

Hampir semua penelitian yang dilakukan menyatakan bahwa success rate untuk faskes yang menjalankan DOTS lebih tinggi dari faskes tanpa DOTS (Pantoja et al., 2006; Sinanovic and Kumaranayake, 2006; Johns et al., 2009). Hal ini membuktikan bahwa penatalaksanaan DOTS di faskes swasta dapat meningkatkan angka keberhasilan pengobatan TB, dan ini sejalan dengan penelitian Ramaiah dan Gawde (2015) di India. Bahkan terjadi peningkatan success rate di faskes DOTS yang semula di India hanya berkisar 70\% menjadi 78\% (Amrita Parida et al., 2014).

Success rate RS Non DOTS pada penelitian ini sebesar 63,89\% juga lebih rendah dibandingkan penelitian di India sebesar 68\% (Amrita Parida et al., 2014), tetapi lebih tinggi dibandingkan studi efektivitas biaya untuk program PPM di negara Vietnam dan India yang berkisar di angka 51\% (Pantoja et al., 2009). Hal ini sejalan dengan kenaikan success rate Indonesia tahun 2017 sebesar 85\% meskipun metode DOTS belum berjalan optimal. Karena pengobatan TB sangat bervariasi tetapi tetap berprinsip pada standar internasional pelayanan TB (International Standard of Tuberculosis Centre / ISTC) (WHO 2017; Kemenkes 2011).

Perbedaan pengalokasian biaya provider berpengaruh pada kenaikan success rate. 24,39\% biaya masyarakat di puskesmas untuk biaya provider, sedangkan RS DOTS mengalokasikan 6,2\% dan RS Non DOTS hanya 0,29\%. Sebagian besar biaya provider digunakan untuk penambahan tenaga pelaksana khusus, dan penambahan biaya ini menjadi daya ungkit kenaikan success rate.

Biaya masyarakat di RS Non DOTS hanya mempunyai perbandingan $90 \%$ dengan biaya masyarakat di RS DOTS. Perbedaan biaya masyarakat/ societal yang tidak terlalu besar antara RS DOTS dan RS Non DOTS dapat disebabkan pelaksanaan JKN tarif INA CBGs sehingga biaya langsung medis untuk penyakit katastropik yang umumnya merupakan OOP (Out of Pocket) pasien dapat ditekan (Tarigan and Suryati, 2017). Penelitian di Jakarta tahun 2016 juga menunjukkan tingkat kepatuhan pasien TB di Jakarta cukup tinggi yaitu $72,2 \%$ dimana tingkat pengetahuan berhubungan secara bermakna dengan kepatuhan berobat TB (Dianasari, Mubasyiroh and Supardi, 2017).

Pada penghitungan nilai ACER didapatkan bahwa puskesmas dengan metode DOTSnya mempunyai biaya penyelenggaraan pengobatan TB paling kecil sehingga terbukti puskesmas merupakan yang paling efektif untuk penanganan TB. Puskesmas sebagai penanggung jawab program di masyarakat hanya membutuhkan biaya Rp 1.948.284 per 1\% kenaikan success rate pasien TB. Hal ini sesuai dengan Permenkes 67 tahun 2016 dimana puskesmas merupakan kepanjangan tangan dari Dinas kesehatan Kota bertanggung jawab atas pelaksanaan program TB di wilayahnya dengan memanfaatkan jejaring faskes di wilayahnya.

Menurut WHO (2016) 36\% kasus TB ada diluar faskes pemerintah, sehingga upaya penemuan 36\% kasus TB yang lain harus bekerjasama dengan pihak faskes swasta. Perhitungan nilai ACER RS Non DOTS 35\% lebih tinggi dibandingkan RS DOTS sedangkan penelitian di Yogyakarta sebesar 300\% perbedaanya (Mahendradhata et,al, 2010). Hasil penghitungan ini mirip dengan penelitian Katherine Floyd,et.al (2011) di India dimana perbedaannya 
hanya $72 \%$ dan 92\% untuk penelitian oleh Ramaiah and Gawde (2015).

Apabila melihat nilai ACER diantara rumah sakit, RS DOTS terbukti cost effective, dimana biaya 4 juta rupiah dengan angka kesuksesan 78\% sedangkan RS Tanpa DOTS mempunyai biaya 5,4 juta rupiah dengan angka kesuksesan 64\%. Hasil penelitian ini menunjukkan RS DOTS lebih menghemat biaya dibandingkan RS Non DOTS sehingga dipertahankan sebagai pilihan dalam pengambilan kebijakan penatalaksanaan TB. Hal ini mendukung implementasi salah satu indikator Standar Pelayanan Minimal (SPM) TBC yaitu menjalin kemitraan dengan pihak fasyankes swasta (Kementrian Kesehatan, 2016).

Pada penelitian ini didapatkan nilai ICER yang paling kecil adalah ICER RS DOTS terhadap RS Non DOTS yaitu sebesar Rp 10.084.572. Artinya untuk menaikkan 1\% angka kesuksesan pengobatan hanya membutuhkan biaya 10 juta rupiah dengan melakukan intervensi program DOTS ke RS Swasta. Penelitian sebelumnya di Indonesia menunjukkan angka ICER sebesar \$351,66 (Rp. 3.235.000) untuk intervensi DOTS ke Dokter Praktek Swasta/DPS (Johns et al., 2009). Penelitian di Brazil tahun 2010 menunjukkan nilai ICER sebesar \$ 6.616 (enam puluh juta rupiah) apabila melakukan intervensi DOTS ke PPM. Dengan demikian, melibatkan faskes swasta dalam penatalaksanaan program TB sebaiknya menggunakan DOTS karena menitikberatkan pada kepentingan kesembuhan pasien.

Penelitian ini mempunyai keterbatasan antara lain pertama biaya pemeriksaan yang dilakukan sebelum diagnosis ditegakkan tidak dimasukkan karena melibatkan banyak faskes. Yang kedua biaya penyelenggara (provider) hanya berasal dari anggaran Dinas Kesehatan Kota Depok, sedangkan biaya penyelenggaraan TB kemungkinan juga dianggarkan oleh instansi lain seperti biaya transport kader di kecamatan atau kelurahan. Yang ketiga adalah pemilihan desain penelitian yang berupa kohort retrospektif dan purposive sampling.

\section{Kesimpulan dan Saran Kesimpulan}

Hasil penelitian dari 36 sampel per kelompok menunjukkan bahwa Success Rate di puskesmas 86,1\%, RS dengan DOTS sebesar 77,78 \% sedangkan yang non DOTS sebesar 63,89\%. Penambahan biaya provider di puskesmas dan RS DOTS meningkatkan success rate. Biaya societal penatalaksanaan TB di puskesmas $42 \%$ dari biaya di RS swasta. Dari perhitungan ACER (Average Cost Effectiveness Ratio) didapatkan bahwa RS yang melaksanakan strategi DOTS lebih cost effective, dengan nilai ACER di Puskesmas adalah Rp 1.948.284, RS DOTS Rp 3.989.576 dan RS Non DOTS sebesar Rp 5.390.323. Untuk menaikkan 1\% angka kesuksesan pengobatan membutuhkan biaya Rp 10.084.572 dengan melakukan intervensi program DOTS ke RS Swasta. Uji t independen menyatakan bahwa terdapat perbedaan bermakna efektivitas biaya perspektif societal pada pengobatan TB di puskesmas, RS DOTS, dan RS Non DOTS .

\section{Daftar Pustaka}

Achmad, Asnawi. 2009. Gambaran Persepsi Pasien terhadap Pelayanan Kesehatan di Puskesmas Sukmajaya Kota Depok Tahun 2009. University of Indonesia. [Accessed: 24 April 2018]. Available at: http://lib.ui.ac.id/file?file=digital/125471-S5706-Gambaran persepsi-Abstrak.pdf.

Amrita Parida et al. . 2014. Comparison of Directly Observed Treatment Short Course (DOTS) with SelfAdministered Therapy in Pulmonary Tuberculosis in Udupi District of Southern India. Journal of Clinical and Diagnostic Research. 8(8): 29-31.

Dianasari, I., Mubasyiroh, R. and Supardi, S. 2017. Hubungan Pengetahuan dan Sikap dengan Kepatuhan Berobat pada Pasien TB Paru yang Rawat Jalan di Jakarta Tahun 2014. Media Penelitian dan Pengembangan Kesehatan. 26(4): 243-248.

Getahun, B. and Nkosi, Z. Z. 2017'Is directly observed tuberculosis treatment strategy patient-centered? A mixed method study in Addis Ababa, Ethiopia. PLOS ONE. Edited by M. Pai. Public Library of Science.12(8): 181-205

Johns, B. et al. 2009. An analysis of the costs and treatment success of collaborative arrangements among public and private providers for tuberculosis control in Indonesia. Health Policy. 93(2-3): 214-224.

Katherine Floyd, VK Arora, KJR Murthy, Knut Lönnroth, Neeta Singla, Y Akbar, Matteo Zignol, \& M. U. 2011. Cost and cost-effectiveness of PPMDOTS for tuberculosis control: evidence from India. Bulletin of WHO. World Health Organization, 84 Number 6(June 2006), pp. 425-504. 1 June 2017. <http://www.who.int/bulletin/ volumes/84/6/floyd0606abstract/en/>.

Laurence, Y. V, Griffiths, U. K. and Vassall, A. 2015. 
Costs to Health Services and the Patient of Treating Tuberculosis: A Systematic Literature Review. PharmacoEconomics. Springer, 33(9): 939-55.

Lemeshow, S. et al. 1990. adequacy of Sample Size in Health Studies. West Sussex: John Wiley \& Sons Ltd. 30 September 2017. <http://apps.who.int/ iris/bitstream/10665/41607/1/0471925179_ eng.pdf $>$.

Mantala, M. J. et al. 2003. Public-private mix DOTS in the Philippines, Tuberculosis. BioMed Central,. 83(1-3): 173-176.

Pantoja, A. et al. 2006. Economic evaluation of public-private mix for tuberculosis care and control, India. Part II. Cost and cost-effectiveness. The International Journal of Tuberculosis and Lung Disease. International Union Against Tuberculosis and Lung Disease. 13 (6): 705-712.

Putri, G. F. and Hisyam. 2014. Hubungan Tingkat Kesembuhan Tuberkulosis Paru Dewasa Dengan Pengobatan Metode DOTS dan Non DOTS di Rumah Sakit Haji Abdoel Madjid Batoe Kabupaten Batanghari Provinsi Jambi Tahun 2011. JKKI. 6(2): 85-94.

Ramaiah, A. A. and Gawde, N. C. 2015a. Economic Evaluation of a Public-Private Mix TB Project in Tamil Nadu, India. Journal of Health Management. SAGE Publications Sage India: New Delhi, India, $17(3)$ : 370-380.

Reviono, R. et al. 2017. The dynamic of tuberculosis case finding in the era of the public-private mix strategy for tuberculosis control in Central Java,
Indonesia. Global Health Action. Taylor \& Francis, $10(1): 1353777$.

Sinanovic, E. and Kumaranayake, L. 2006. Financing and cost-effectiveness analysis of public-private partnerships: provision of tuberculosis treatment in South Africa. Cost Effectiveness and Resource Allocation. 4(1): 11 .

Steffen, R. et al. 2010. Patients' costs and costeffectiveness of tuberculosis treatment in DOTS and non-DOTS facilities in Rio de Janeiro, Brazil.' PloS one. Public Library of Science. 5(11): e14014.

Suhariadi, F. et al. 2016. The tale of seeking treatment: A qualitative study of pulmonary tuberculosis patients. Psychology, Community \& Health, 5(3): 229-243.

Tarigan, I. and Suryati, T. 2017. Gambaran Out of Pocket pada Awal Era JKN di Indonesia. Ejournal. Litbang.Depkes.Go.Id. 1(2): 141-146.

WHO. 2016. Global Tuberculosis Report 2016. 3 June 2017. <http://www.who.int/tb/publications/ global_report/gtbr2016_executive_summary. $\mathrm{pdf}>$.

WHO. 2017. Public-Private Mix for TB Care and Control - A toolkit. 1 June 2017. <http://www. who.int/tb/careproviders/ppm/PPMToolkit.pdf>.

Mahendradhata, Y. et al. 2010. The Incremental Cost-Effectiveness of Engaging Private Practitioners to Refer Tuberculosis Suspects to DOTS Services in Jogjakarta, Indonesia. Am. J. Trop. Med. Hyg. 82(6): 1131-1139. 